\title{
ТАКСОНОМІЧНА ТА БІОЛОГО-ЕКОЛОГІЧНА ОЦІНКА ВИДІВ АЛЬПІЙСЬКИХ РОСЛИН НА КАМ'ЯНИСТІЙ ГІРЦІ ВІННИЦЬКОГО НАЦІОНАЛЬНОГО АГРАРНОГО УНІВЕРСИТЕТУ
}

\begin{abstract}
Підібрано 39 видів рослин для створення кам'янистої гірки. Серед них 5 видів є дикорослими в умовах Поділля, а інші 34 види інтродуковані з інших зон і культивовані в наших умовах. Охарактеризовано, що природним ареалом походження досліджуваних рослин є: Китай, Японія, Корея, Азія, Росія, Сибір, Далекий Схід, Україна, Балкани. Переважна частина інтродуцентів походить із Північної Америки, Свропи та Кавказу. Визначено, що всі підібрані інтродуценти добре ростуть та розвиваються в умовах Поділля. Встановлено, що всі підібрані дикорослі рослини Поділля відмінно прижилися на кам'янистій гірці. Досліджено, що переважаючим у таксономічній структурі культивованої флори кам'янистої гірки $\epsilon$ відділ Magnoliophyta - 38 видів. Таксономічний аналіз показав, що панівними за кількістю таксонів є родини Crassulaceae (9 видів) і Rosaceae (4 види). Серед підібраних рослин для влаштування кам'янистої гірки відносно вологи переважають мезофіти (22 види або 56 \% від загальної кількості), щодо світла переважають світлолюбні види - 90 \% (35 видів), а що до температури повітря - морозостійкі рослини. Доведено, щоб кам'яниста гірка мала привабливий декоративний вигляд у будь-який сезон. Потрібно правильно розташувати на ній рослини, які у період цвітіння будуть гармонійно поєднуватись між собою. Підібраний асортимент рослин забезпечує цвітіння кам'янистої гірки, починаючи з третьої декади лютого і завершуючи в останню декаду жовтня.
\end{abstract}

Ключові слова: сад; квітник; інтродуцент; флора; цвітіння; альпінарій.

Вступ. Кам'янистий сад - особливий вид квітника, оригінальний прийом садового дизайну, що дає змогу імітувати гірський ландшафт. Більшість рослин, яких насаджують у такому квітнику, є родом з альпійського і субальпійського гірських поясів, тому такі сади часто називають альпінаріями або "альпійськими гірками". Кам'янистий квітник можна створити на ділянці з будьяким рельєфом. Якщо це височина, то можемо назвати його "кам'янистою гіркою". Якщо ж це рівне місце, схил, яр або канава, то квітник може мати вигляд підпірної стінки, тераси або складної композиції з усіх зазначених вище елементів, з'єднаних сходами і доріжками (Chernyak \& Prokopchuk, 1994).

Квітник із використанням каменю може стати головною прикрасою декоративної частини саду. Він прекрасно гармонуе з газоном, брукованими поверхнями i водоймою. Будь-яка 3 комбінацій цих декоративних елементів створює чудову композицію. Розмістити кам'янистий сад можна на сонці або в тіні, в посушливому або навіть у заболоченому місці. Важливо лише правильно підібрати асортимент рослин, який відповідає цим умовам. Бажано розташувати його осторонь від пишних яскравих квітників, подалі від господарської зони, в місці, що де можна спокійно насолоджуватися красою скромних, але вишуканих гірських рослин (Landscaping, 2010).

Будівництво кам'янистої гірки - процес творчий, що потребує знань і досвіду. Двох однакових кам'янистих гірок не існує, як не має в природі двох однакових каменів - все залежить від фантазії творців цих декоративних садових елементів.

В Україні кам'янисті гірки донедавна не часто встановлювали і спочатку споруджувалися лише в ботанічних садах, потім у парках та скверах деяких міст. А нині дедалі частіше їх використовують ландшафтні дизайнери. Здебільшого для облаштування альпінаріїв насаджують високогірні рослини альпійської флори. Втім, коли за мету створення взято її декоративність, висаджують і звичайні види рослин.

Сьогодні створення кам'янистої гірки є дуже популярним і прибутковим. Це не дивно, адже вона вдало прикрасить будь-яку ділянку або навіть може стати центром усієї композиції. Більшість гірок створюють 3 декоративною метою, тому дуже важливо, щоб композиція виглядала природно і гармонійно вписувалась у навколишній ландшафт. При цьому необхідно враховувати такі вимоги, як: освітленість території, рельєф, експозицію схилів, а також характер навколишнього сере-

Інформація про авторів:

Прокопчук Валентина Мар'янівна, канд. біол. наук, доцент, кафедра лісового, садово-паркового господарства, садівництва та виноградарства. Email: monarhinya@ukr.net

Монарх Вероніка Валентинівна, канд. с.-г. наук, ст. викладач, кафедра лісового, садово-паркового господарства, садівництва та виноградарства. Email: monarhinya@ukr.net; https://orcid.org/0000-0002-4473-7683

цитування за ДСту: Прокопчук В. М., Монарх В. В. Таксономічна та біолого-екологічна оцінка видів альпійських рослин на кам'янистій гірці Вінницького національного аграрного університету. Науковий вісник НЛТУ України. 2019, т. 29 , № 2. С. $73-76$.

Citation APA: Prokopchuk, V. M., \& Monarkh, V. V. (2019). Taxonomic and biological-environmental assessment of alpine plant species on the alpine slide of VNAU. Scientific Bulletin of UNFU, 29(2), 73-76. https://doi.org/10.15421/40290214 
довища (Chernyak \& Prokopchuk, 1994; Landscaping, 2010).

Об'єктом дослідження є види альпійських рослин кам'янистої гірки, створеної на базі біостаціонару Вінницького національного аграрного університету (ВНАУ).

Мета роботи полягає у дослідженні таксономічних та біолого-екологічних особливостей видів альпійської флори на кам'янистій гірці в умовах біостаціонару BНАУ.

Завдання дослідження - підібрати дикорослі та інтродуковані види Поділля; провести таксономічний та біолого-екологічний аналіз видів кам'янистої гірки; зробити аналіз щодо пристосування підібраних видів альпійської флори до умов біостаціонару ВНАУ.

Матеріали і методи дослідження. Об'єктом дослідження є види альпійських рослин кам'янистої гірки, створеної на базі біостаціонару ВНАУ. Для створення кам'янистої гірки було підібрано 39 видів рослин. Серед них 5 видів є дикорослими в умовах Поділля, а інші 34 види інтродуковані з інших зон і культивовані в наших умовах. Безпосередньо рослинами, природним ареалом яких є альпійська місцевість, є 32 види: бересклет Форчуна (Euonymus fortunei); кизильник горизонтальний (Cotoneaster horizontalis Decne); спірея японська 'Голдфлейм' (Spiraea japonica L. $f$. 'Goldflame') та 'Літл Прінцес' (S. japonica L. $f$. 'Little Princess'); перстач білий (Potentilla alba L.); ялівець горизонтальний (Juniperus horizontalis); герань великокореневищна (Geranium macrorrhizum); ірис карликовий (Iris pumila L.); костриця сиза (Festuca glauca); лаванда вузьколиста (Lavandula angustifolia Mill.); молодило покрівельне (Sempervivum tectorum L.); очиток білий (Sedum album); очиток відхилений (Sedum reflexum L.); очиток гібридний (Sedum hybridum); очиток густолистий (Sedum dasyphyllum C. А. Меу); очиток Еверса (Sedum ewersii); очиток Зібольда (Sedum sieboldii); очиток їдкий (Sedum acre L.); очиток звичайний (Pulsatilla patens (L.) Mill.); простріл розкритий (Sedum telephium); роговик Біберштейна (Cerastium biebersteinii DC.); рудбекія блискуча (Rudbeckia fulgida); флокс шилоподібний (Phlox subulata L.); хоста ланцетолиста (Hosta lancifolia Engl.); гвоздика китайська (Dianthus chinensis L.); ешольція каліфорнійська (Eschscholzia californica); лобулярія приморська (Lobularia maritime L.); портулак великоквітковий (Portulaca grandiflora); крокус весняний (Crocus vernus L.); мускарі вірменський (Muscari armeniacum); нарцис вузьколистий (Narcissus angustifolius L. subsp); підсніжник білосніжний (Galanthus nivalis L.); тюльпан карликовий (Tulipa humilis Herb).

До флори кам'янистої гірки також належать рослини, що не $є$ природними альпійцями: гейхера волосиста (Heuchera villosa Michx); гейхера дрібноквіткова 'Палас Пурпл' (Heuchera micrantha 'Palace Purple'); манжетка м'яка (Alchemilla mollis); бархатці розлогі (Tagetes erecta L.); лаватера тримісячна 'Silver Cup' (Lavatera trimestris L. 'Silver Cup'); лантана шиповата 'Fabiola' (Lantana camara L. 'Fabiola'); чорнушка посівна (Nigella sati$v a)$. Такий підбір виконано з метою порівняння пристосування різних видів рослин до умов біостаціонару BНАУ.

Під час роботи над створенням кам'янистої гірки було застосовано метод польового дослідження та вивчення в камеральних умовах. Таксономічну структуру встановлювали, використовуючи такі видання:
Ю. Г. Гамуля (Gamulya \& Utevska, 2011), Ю. Я. Слін та інші (Elin, Zerova, Lushpa \& Shabrova, 1979), Д. Н. Доброчаєва та інші (Dobrochaeva, Kotov \& Prokudin, 1987), А. I. Толмачов (Tolmachyov, 1970). Морфо-біологічні, біолого-екологічні особливості рослин та їх використання описували за даними таких авторів: Б. Н. Головкін та ін. (Golovkin, Kitaeva \& Nemchenko, 1986), В. П. Кучерявий (Kucheryaviy, 2004), Ю. Нестерук (Nesteruk, 2003), А. Л. Липа (Lyipa, 1952). Латинські та українські назви видів альпійських рослин наводили за В. Водічковою (Vodichkova \& Kaplitskaya, 1989) та I. Крейчею (Kreycha \& Yakobova, 1986).

Підбір рослин за морфо-біологічними ознаками проводили за рекомендаціями ландшафтного архітектора T. Науменко (Naumenko, 2012) і авторів Р. А. Карпісонової (Karpisonova, 2008), Ф. Келайна (Kelayn, Mentsel \& Bertele, 2006), Ю. С. Кір'янової (Kiryanova, 2009). Під час підбору рослин за термінами цвітіння користувалися методикою ландшафтного дизайнера Л. Рековець (Rekovets \& Rekovets, 2006).

Визначення інтродукованих видів підібраних альпійських рослин та природного ареалу їх поширення проводили за даними А. Л. Липи (Lyipa, 1978), М. А. Кохно та ін. (Kohno \& Kurdyuk, 1994), А. М. Гродзинського (Grodzinskiy, 1978), П. Я. Чуприни та ін. (Chuprina \& Gordienko, 1978). Для визначення дикорослих рослин Поділля використовували дані таких авторів, як: Ю. Г. Гамуля (Gamulya \& Utevska, 2011) i В. I. Чопик та ін. (Chopik, Dudchenko \& Krasnova, 1983). Декоративний аналіз інтродукованих та дикорослих рослин на кам'янистій гірці проводили за методичними розробками В. В. Лещинської (Leschinskaya, 2011) та Л. Г. Павленка (Pavlenko, 2005).

Результати дослідження. Головним елементом кам'янистої гірки є рослини, причому вважають, що на такій гірці мають рости тільки представники високогірної альпійської флори. Це твердження є помилковим, оскільки досвід показав, що і рослини місцевої флори досить вдало вписуються у кам'янистий ландшафт.

Отже, для влаштування кам'янистої гірки було підібрано 39 видів рослин, природним ареалом походження яких є: Китай, Японія, Корея, Азія, Росія, Сибір, Далекий Схід, Україна, Балкани тощо. Переважна частина інтродуцентів походить із Північної Америки, Свропи та Кавказу. На рисунку наведено відсоткове співвідношення між інтродукованими та дикорослими видами.

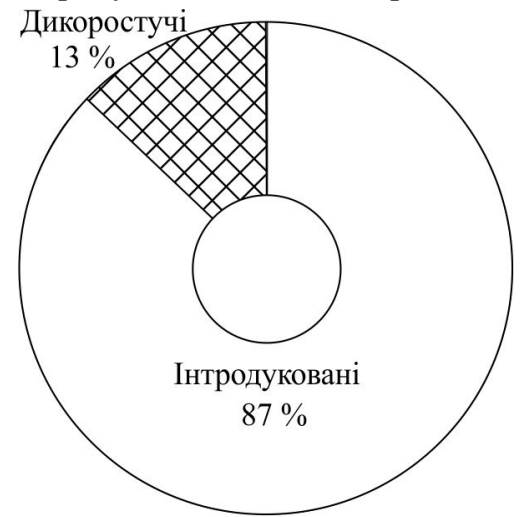

Рисунок. Спектр розподілу інтродукованих та дикорослих рослин Поділля для створення кам'янистої гірки

Внаслідок проведених досліджень визначено, що всі підібрані інтродуценти добре ростуть та розвиваються в умовах Поділля. Проте такі види, як: манжетка м'яка ( $A$. 
mollis), роговик Біберштейна (C. biebersteinii) і сорт спіреї японської 'Голдфлейм' (S. japonica 'Goldflame'), погано перенесли пересадку. Проте вже після двох тижнів адаптації на новому місці ріст та розвиток рослин відновився. Підібрані дикорослі рослини Поділля відмінно прижилися на кам'янистій гірці.

У табл. 1 відображено таксономічну структуру культивованої флори кам'янистої гірки.

Табл. 1. Таксономічна структура культивованої флори кам'янистої гірки на базі біостаціонару ВНАУ

\begin{tabular}{|c|l|c|c|c|c|c|c|}
\hline \multirow{2}{*}{$\begin{array}{c}\text { № } \\
\text { 3/п }\end{array}$} & Відділ & $\begin{array}{c}\text { кла- } \\
\text { сів }\end{array}$ & $\begin{array}{c}\text { поряд- } \\
\text { ків }\end{array}$ & $\begin{array}{c}\text { ро- } \\
\text { дин }\end{array}$ & родів & видів & $\begin{array}{c}\text { сор- } \\
\text { тів }\end{array}$ \\
\hline 1 & $\begin{array}{l}\text { Голонасінні } \\
\text { (Pinophyta) }\end{array}$ & 1 & 1 & 1 & 1 & 1 & 1 \\
\hline 2 & $\begin{array}{l}\text { Покритонасінні } \\
\text { (Magnoliophyta) }\end{array}$ & 2 & 14 & 21 & 30 & 38 & 6 \\
\hline \multicolumn{2}{|c|}{ Разом } & 3 & 15 & 22 & 31 & 39 & 6 \\
\hline
\end{tabular}

Як видно 3 табл. 1, переважаючим у таксономічній структурі культивованої флори кам'янистої гірки є відділ Magnoliophyta - 38 видів (97 \% від загальної кількості), який включає 2 класи, 14 порядків, 21 родину, 30 родів і 6 сортів. Відділ Pinophyta нараховує лише 1 вид (3 \% від загальної кількості), відповідно стільки ж становить кількість класів, порядків, родин і родів.

Систематична структура флори визначає розподіл видів між систематичними категоріями вищого рангу. Для ширшого аналізу та порівняння систематичних одиниць у табл. 2 наведено систематичну структуру культивованої флори кам'янистої гірки. Дані свідчать про кількісну характеристику видового складу основних таксономічних одиниць та видову насиченість провідних родин та родів.

Табл. 2. Систематична структура культивованої флори кам'янистої гірки на базі біостаціонару ВНАУ

\begin{tabular}{|c|c|c|c|c|}
\hline \multirow{2}{*}{$\begin{array}{c}\text { № } \\
\text { 3/П } \\
\end{array}$} & \multirow[t]{2}{*}{ Родина } & \multicolumn{3}{|c|}{$\begin{array}{l}\text { Систематична оди- } \\
\text { ниця, кількість, шт. }\end{array}$} \\
\hline & & родів & видів & сортів \\
\hline \multicolumn{5}{|c|}{ Відділ Голонасінні (Pinophyta) } \\
\hline 1 & Кипарисові (Cupressaceae) & 1 & 1 & - \\
\hline \multicolumn{5}{|c|}{ Відділ Покритонасінні (Magnoliophyta) } \\
\hline 2 & Бруслинові (Celastraceae) & 1 & 1 & - \\
\hline 3 & Розові (Rosaceae) & 4 & 4 & 2 \\
\hline 4 & Ломикаменеві (Saxifragaceae) & 1 & 2 & 1 \\
\hline 5 & Геранієві (Geraniaceae) & 1 & 1 & - \\
\hline 6 & Півникові (Iridaceae) & 2 & 2 & - \\
\hline 7 & Тонконогові (Роасеае) & 1 & 1 & - \\
\hline 8 & Глухокропивові (Lamiaceae) & 1 & 1 & - \\
\hline 9 & Товстолисті (Crassulaceae) & 2 & 9 & - \\
\hline 10 & Жовтецеві (Ranunculaceae) & 2 & 2 & - \\
\hline 11 & Гвоздичні (Caryophyllaceae) & 2 & 2 & - \\
\hline 12 & Айстрові (Asteraceae) & 2 & 2 & - \\
\hline 13 & Синюхові (Polemoniaceae) & 1 & 1 & - \\
\hline 14 & Холодкові (Asparagaceae) & 2 & 2 & - \\
\hline 15 & Макові (Papaveraceae) & 1 & 1 & - \\
\hline 16 & Мальвові (Malvaceae) & 1 & 1 & 1 \\
\hline 17 & Вербенові (Verbenaceae) & 1 & 1 & 1 \\
\hline 18 & Капустяні (Brassicaceae) & 1 & 1 & - \\
\hline 19 & Портулакові (Portulacaceae) & 1 & 1 & 1 \\
\hline 20 & Амарилісові (Amaryllidaceae) & 2 & 2 & - \\
\hline 21 & Лілійні (Liliaceae) & 1 & 1 & - \\
\hline & Всього & 31 & 39 & 6 \\
\hline
\end{tabular}

Таксономічний аналіз показав, що панівними за кількістю таксонів є родини Crassulaceae (9 видів) і Rosaceae (4 види). По 2 види налічують родини: Saxifragaceae, Iridaceae, Ranunculaceae, Caryophyllaceae, Asteraceae, Asparagaceae та Amaryllidaceae. Лише одним видом представлені 12 родин (Cupressaceae, Celastraceae,
Geraniaceae, Poaceae, Lamiaceae, Polemoniaceae, Papaveraceae, Malvaceae, Verbenaceae, Brassicaceae, Portulacaceae та Liliaceae).

Обговорення отриманих результатів. Біолого-екологічні особливості рослин передбачають аналіз їх відношення і вимоги до умов навколишнього середовища, зокрема до умов зволоження, освітлення, температури повітря і грунту, родючості грунту та інших екологічних чинників.

Серед підібраних рослин для влаштування кам'янистої гірки відносно вологи переважають мезофіти (22 види, або $56 \%$ від загальної кількості), немалу частку займають також ксерофіти (16 видів, або $41 \%$ ) і лише один вид (3\%) - Рудбекія блискуча (R. fulgida) - $\epsilon$ гігрофітом. Щодо світла переважають світлолюбні види $90 \%$ (35 видів), а щодо температури повітря - морозостійкі рослини ( $82 \%$ або 32 види). За відношенням до родючості грунту мезотрофи становлять $54 \%$ (21 вид), оліготрофи - 46 \% (18 видів), мегатрофи відсутні.

Важливим чинником під час підбору альпійських рослин для кам'янистої гірки $є$ період їх цвітіння. Необхідно сформувати такий асортимент рослин, який забезпечить квітування гірки від ранньої весни до пізньої осені.

Серед 39 видів досліджуваних рослин не квітучими є 3 види - бересклет Форчуна (E. fortunei), ялівець горизонтальний (J.horizontalis) і костриця сиза ( $F$. glauca). Решта 37 видів характеризуються цвітінням у різні періоди року. Проте серед рослин є види, що більше цінуються як декоративно-листяні, оскільки не мають ефектного цвітіння. До них належать: кизильник горизонтальний (C. horizontalis), гейхера волосиста (H. villosa), гейхера дрібноквіткова 'Палас Пурпл' (H. micrantha 'Palace Purple'), манжетка м'яка (A. mollis) і молодило покрівельне (S. tectorum).

Щоб кам'яниста гірка мала привабливий декоративний вигляд у будь-який сезон, необхідно правильно розташувати на ній рослини, які в період цвітіння будуть гармонійно поєднуватись між собою. Підібраний асортимент рослин забезпечує цвітіння кам'янистої гірки, починаючи з третьої декади лютого (підсніжник білосніжний (G. nivalis)) і завершуючи в останню декаду жовтня (очиток Зібольда (S. sieboldii), лаватера тримісячна 'Silver Cup' (L. trimesrtris 'Silver Cup'), лобулярія приморська (L. maritima), ешольція каліфорнійська $(E$. californica)).

Весняне цвітіння забезпечують такі цибулеві види, як мускарі вірменський (M. armeniacum), крокус весняний (C. vernus), нарцис вузьколистий (N. angustifolius) i тюльпан карликовий (T. humilis). Також у цей період квітує простріл розкритий (P. patens). Найінтенсивніше цвітіння спостерігаємо з першої декади червня по другу декаду жовтня.

Висновки. Створена кам'яниста гірка позитивно впливає на умови біостаціонару ВНАУ. По-перше, гірка $\epsilon$ сприятливим місцем для зростання альпійських видів. По-друге, альпійська рослинність завдяки своїй здатності розростатися і покривати грунт завадить росту i розвитку бур'янів. По-третє, терасований схил запобігає застосуванню дощових і талих вод та розмиву грунту на цій території. І по-четверте, вона є дуже декоративною і покращує загальний вигляд композиції ландшафту. 


\section{Перелік використаних джерел}

Chernyak, V. M., \& Prokopchuk, L. A. (1994). Kamyanista gIrka yak obekt navchalno-vihovnoyi roboti v shkoli. [Alpine slide]. (Ser. biologiya, himiya, pedagogika). Naukovi zapiski Ternopilskogo pedagogIchnogo institutu, 1, 79-81. [In Ukrainian].

Chopik, V. I., Dudchenko, L. G., \& Krasnova, A. N. (1983). Wild useful plants of Ukraine. Kyiv: Naukova dumka, 400 p. [In Russian].

Chuprina, P. Ya., \& Gordienko, I. I. (1978). Poshirennya introdukovanih golonasinnih roslin v Polissi, Lisostepu, Prikarpatti ta Zakarpatti Ukrayini. [Plant introduction]. Introduktslya $i$ aklImatizatsiya roslin na Ukrayini, 12, 52-61. [In Ukrainian].

Dobrochaeva, D. N., Kotov, M. I., \& Prokudin, Yu. N. (1987). Determination of higher plants of Ukraine. Kyiv: Naukova dumka, 548 p. [In Russian].

Elin, Yu.Ya., Zerova, M. Ya., Lushpa, V. I., \& Shabrova, S. I. (1979). Forest plants. Kyiv: Urozhay, 440 p. [In Ukrainian].

Gamulya, Yu. G., \& Utevska, O. M. (Ed.). (2011). Plants of Ukraine. Kharkiv: Faktor, 208 p. [In Ukrainian].

Golovkin, B. N., Kitaeva, L. A., \& Nemchenko, E. P. (1986). Dekorativnyie rasteniya SSSR. [Decorative plants]. Moscow: Myisl, $320 \mathrm{p}$. [In Russian].

Grodzinskiy, A. M. (1978). Do sistemi uyavlen pro introduktsiyu i aklimatizatsIyu roslin. IntroduktsIya i aklimatizatsiya roslin na Ukrayini. Introduction and acclimatization in Ukraine, 12, 3-7. [In Ukrainian].

Karpisonova, R. A. (2008). Device. Care. Vegetation. Moscow: Kladez-Buks, 127 p. [In Russian].

Kelayn, F., Mentsel, P., \& Bertele, A. (2006). Encyclopedia of garden plants: flowers, trees, shrubs. Moscow: AST "Astrel", 639 p. [In Russian].

Kiryanova, Yu. S. (2009). Kratkaya entsiklopediya sadovogo dizayna. Sovremennyiy landshaftnyiy dizayn vashego sada. [Garden design encyclopedia]. Moscow: AST, 238 p. [In Russian].
Kohno, N. A., \& Kurdyuk, A. M. (1994). Introduction of woody plants in Ukraine. Kyiv: Naukova dumka, 188 p. [In Russian].

Kreycha, I., \& Yakobova, A. (1986). Alpine slide in the garden. Bratislava: Priroda, 310 p. [In Russian].

Kucheryaviy, V. P. (2004). Planting of settlements. Lviv: Svit, 450 p. [In Ukrainian]

Landscaping. (2010). Blagoustroystvo uchastka ot landshaftnogo dizayna do sadovyih postroek. Bolshaya entsiklopediya. Minsk: Harvest, 224 p. [In Russian].

Leschinskaya, V. V. (2011). Garden design. Moscow: Adelant, 120 p. [In Russian].

Lyipa, A. L. (1952). Dendrologicheskie bogatstva Ukrainskoy SSR $i$ ih ispolzovanie. [Plants and architecture]. Ozelenenie naselennyih mest. Kyiv: Izd-vo Akad. arhitekturyi USSR, 521 p. [In Russian].

Lyipa, A. L. (1978). Introduction and acclimatization of woody plants in Ukraine. Kyiv: Vischa shkola izd-vo pri Kiev. un-te, 109 p. [In Russian].

Naumenko, T. (2012). Kamenistyie sadyi. [Gardens in which stones are used for design]. Ogorodnik, 37-39.

Nesteruk, Yu. (2003). Vegetable world of the Ukrainian Carpathians: Chornogora. EkologIchni mandrivki. Lviv: BaK, 520 p. [In Ukrainian].

Pavlenko, L. G. (2005). Landscaping design. Dizayn sada. Rostov-onDon: Feniks, 192 p. [In Russian].

Rekovets, L., \& Rekovets, P. (2006). Creature alpine slide. Lisoviy $i$ mislivskiy zhurnal, 2, 22-23. [In Ukrainian].

Tolmachyov, A. I. (1970). O nekotoryih kolichestvennyih sootnosheniyah vo florah Zemnogo shara. [The flora of the globe]. Vestnik $L G U, 3,62-74$. [In Russian].

Vodichkova, V., \& Kaplitskaya, I. (1989). Alpinariy. [Alpine slide]. Praga: Artiya, 224 p. [In Ukrainian].

V. M. Prokopchuk, V. V. Monarkh

Vinnvtsia National Agrarian University, Vinnytsia, Ukraine

\title{
TAXONOMIC AND BIOLOGICAL-ENVIRONMENTAL ASSESSMENT OF ALPINE PLANT SPECIES ON THE ALPINE SLIDE OF VNAU
}

\begin{abstract}
The creation of an alpine slide is now very popular and profitable. It is not surprising, because it successfully decorates any plot, or even can become the center of the entire composition. Most slides are created for decorative purposes, so it is very important for the composition to look naturally, and harmoniously fit into the surrounding landscape. It is necessary to take into account a number of requirements, such as illumination of the territory, relief, exposure of slopes, as well as the nature of the environment. The purpose of the work is to study the taxonomic and biological-ecological features of the species of alpine flora on a slide in the conditions of the Biological Stationary of VNAU. There were selected 39 species of plants to create a slide. Among them, 5 species are wild in Podillya, and the other 34 species are introduced from other zones and cultivated in our conditions. It has been characterized that the natural range of origin of the studied plants is: China, Japan, Korea, Asia, Russia, Siberia, the Far East, Ukraine, the Balkans, etc. The bulk of the introducents come from North America, Europe and the Caucasus. It is determined that all selected introducents grow well and develop in conditions of Podillya. It is established that all selected wild plants of Podillya fitted well on a slide. It was investigated that the dominant in the taxonomic structure of the cultivated flora of the rocky slide is the Family of Magnoliophyta 38 species. Taxonomic analysis showed that the dominant in the number of taxa are the families Crassulaceae ( 9 species) and Rosaceae (4 species). Among the selected plants for the arrangement of a rocky slide in relation to moisture are dominated by mesophytes ( 22 species or $56 \%$ of the total), in relation to the light dominated light-loving species $-90 \%$ ( 35 species), and to the temperature of air - frost resistant plants. It is proved that the slide has an attractive decorative look in any season, it is necessary to properly plant on it, which during the flowering period will be harmoniously interconnected. The assortment of plants provides the flowering of a rocky slide, starting from the third decade of February and completing in the last decade of October.
\end{abstract}

Keywords: garden; flower bed; introducent; flora; flowering; alpine slide. 